\title{
Elevated Levels of Interferon-y Production by Memory T Cells Do Not Promote Transplant Tolerance Resistance in Aged Recipients
}

\section{Citation}

Kim, James I., Ryan T. Stott, Julie Soohoo, Kang Mi Lee, Gaoping Zhao, Heidi Yeh, Shaoping Deng, and James F. Markmann. 2013. "Elevated Levels of Interferon-y Production by Memory T Cells Do Not Promote Transplant Tolerance Resistance in Aged Recipients." PLoS ONE 8 (12): e82856. doi:10.1371/journal.pone.0082856. http://dx.doi.org/10.1371/journal.pone.0082856.

\section{Published Version}

doi:10.1371/journal.pone.0082856

\section{Permanent link}

http://nrs.harvard.edu/urn-3:HUL.InstRepos:11879347

\section{Terms of Use}

This article was downloaded from Harvard University's DASH repository, and is made available under the terms and conditions applicable to Other Posted Material, as set forth at http:// nrs.harvard.edu/urn-3:HUL.InstRepos:dash.current.terms-of-use\#LAA

\section{Share Your Story}

The Harvard community has made this article openly available.

Please share how this access benefits you. Submit a story.

Accessibility 


\title{
Elevated Levels of Interferon- $y$ Production by Memory $T$ Cells Do Not Promote Transplant Tolerance Resistance in Aged Recipients
}

\author{
James I. Kim¹, Ryan T. Stott', Julie Soohoo', Kang Mi Lee', Gaoping Zhao',2, Heidi Yeh', Shaoping \\ Deng $^{1,2}$, James F. Markmann ${ }^{1 *}$
}

1 Transplantation Unit, Department of Surgery, Massachusetts General Hospital, Harvard Medical School, Boston, Massachusetts, United States of America, 2 Department of Surgery, Sichuan Provincial People's Hospital and Sichuan Academy of Medical Sciences, Chengdu, Sichuan Province, China

\begin{abstract}
Immunosenescence predisposes the elderly to infectious and autoimmune diseases and impairs the response to vaccination. We recently demonstrated that ageing also impedes development of transplantation tolerance. Unlike their young counterparts (8-12 weeks of age) aged male recipients (greater than 12 months of age) transplanted with a full MHC-mismatched heart are resistant to tolerance mediated by anti-CD45RB antibody. Surprisingly, either chemical or surgical castration restored tolerance induction to levels observed using young recipients. Based on the strong impact of endocrine modulation on transplant tolerance, we explored the impact of ageing and castration on the immune system. Here we report a significant increase in the percentage of T cells that produce interferon- $Y$ (IFN$\mathrm{Y}$ ) in aged male versus young male animals and that the overall increase in IFN- $\mathrm{Y}$ production was due to an expansion of IFN- $\mathrm{Y}$-producing memory T cells in aged animals. In contrast to IFN- $\mathrm{Y}$ production, we did not observe differences in IL-10 expression in young versus old male mice. We hypothesized that endocrine modulation would diminish the elevated levels of IFN-y production in aged recipients, however, we observed no significant reduction in the percentage of IFN- $\gamma^{+} \mathrm{T}$ cells upon castration. Furthermore, we neutralized interferon- $\gamma$ by antibody and did not observe an effect on graft survival. We conclude that while elevated levels of interferon- $\gamma$ serves as a marker of tolerance resistance in aged mice, other as yet to be identified factors are responsible for its cause. Defining these factors may be relevant to design of tolerogenic strategies for aged recipients.
\end{abstract}

Citation: Kim JI, Stott RT, Soohoo J, Lee KM, Zhao G, et al. (2013) Elevated Levels of Interferon-y Production by Memory T Cells Do Not Promote Transplant Tolerance Resistance in Aged Recipients. PLoS ONE 8(12): e82856. doi:10.1371/journal.pone.0082856

Editor: Paolo Fiorina, Children's Hospital Boston/Harvard Medical School, United States of America

Received October 7, 2013; Accepted October 28, 2013; Published December 10, 2013

Copyright: $\odot 2013 \mathrm{Kim}$ et al. This is an open-access article distributed under the terms of the Creative Commons Attribution License, which permits unrestricted use, distribution, and reproduction in any medium, provided the original author and source are credited.

Funding: Funding provided by National Institutes of Health (NIH) RO1AI057851-05 (JFM), NIH K08-DK094965 (HY), and NIH 5T32AI7529 (KML). The funders had no role in study design, data collection and analysis, decision to publish, or preparation of the manuscript.

Competing interests: The authors have declared that no competing interests exist.

*E-mail: jmarkmann@partners.org

\section{Introduction}

The elderly are the fastest growing segment of the population with end-stage organ disorders, and their numbers on the transplant waiting list continue to rise [1-4]. By 2020, for the first time in human history, the number of people older than 65 will outnumber the number of children under 5 [5]. Induction of durable donor specific tolerance could allow successful transplantation without the morbidity of immunosuppression $[6,7]$. To be broadly applicable, it will need to succeed in recipients of all ages, yet clinical and laboratory transplant tolerance induction protocols almost exclusively rely on young recipients. Furthermore, the majority of basic science research in tolerance takes place in young animals. Thus, in order for tolerance to become a reality for the majority of transplant patients, it is essential to understand the effects of ageing on transplant tolerance.

Due to a decline in immune function, the elderly are more susceptible to infectious disease and malignancy, while exhibiting an impaired response to vaccination [8-10]. At the cellular level, ageing is associated with a decrease in the number of naive lymphocytes, a decreased proliferation of CD4+CD25- $T$ cells, and a decreased response to mixed lymphocyte reaction $[11,12]$. This would suggest that tolerance might be more easily achievable in the elderly, but immunosenescence is also accompanied with increased autoimmune disease and cardiovascular disease, in which an over-reactive immune response is thought to play a role perhaps suggesting some loss of regulation [13-15]. In addition, an increase in the ratio of memory to naive $T$ cells (Tnaive) is seen in observed in older humans and mice 
[16], and memory T cells (Tmem) have a decreased threshold of activation and are resistant to costimulatory blockade [17]. IFN- $\mathrm{Y}$ production by memory $\mathrm{T}$ cells is also associated with acute renal rejection $[18,19]$.

Donor age, recipient age, and donor-recipient age difference all influence graft survival [20-25]. In a study of nearly 49,000 kidney transplant recipients, graft loss associated with acute rejection episodes was considerably higher in elderly recipients; five-year death censored kidney graft survival was $59.9 \%$ for recipients over age 65 versus $82 \%$ for recipients under age 35 [25]. This suggests that the elderly may require more intense conditioning protocols for tolerance induction, which is complicated by the fact that immunosuppressive therapy also carries higher morbidity for elderly patients $[24,26]$.

We have observed that a short course of anti-CD45RB reliably induces stable, robust tolerance to various allogeneic grafts in young mice but never in aged mice [27-29]. In a cardiac transplant model, over half of heart grafts survived long-term in young male recipients, while in old male recipients, all grafts were rejected quickly. Recently, T cell interferon- $\gamma$ production has been reported to play a key role in agedependent tolerance resistance [30]. We hypothesized that the increased proportion of IFN- $\gamma$ producing memory $\mathrm{T}$ cells impairs tolerance induction in aged mice, and that castration returns IFN-y production to normal levels.

\section{Materials and Methods}

\section{Mice}

Male $\mathrm{C} 3 \mathrm{H} / \mathrm{HeJ}$ and $\mathrm{C} 57 \mathrm{BL} / 6$, aged 8 to 10 weeks, were purchased from Jackson Labs (Bar Harbor, Maine). All mice were housed under specific pathogen-free conditions in approved plastic cages in the animal facility of Massachusetts General Hospital. Mice were randomized to control and experimental groups. Mice were housed 4 per cage under standard conditions at constant temperature, humidity, and light/dark cycles, and provided with food and water ad libitum.

All protocols detailed below were performed following the principles of laboratory animal care and approved by the $\mathrm{MGH}$ Institutional Animal Care and Use Committee (\#2007N000023). The protocol conforms to the USDA Animal Welfare Act, PHS Policy on Humane Care and Use of Laboratory Animals, the "ILAR Guide for the Care and Use of Laboratory Animals" and other applicable laws and regulations. All efforts were made to minimize suffering.

\section{Transplantation}

Skin grafts were transplanted to mice according to the technique of Billingham and Medawar [31] as previously described. 100 ug of anti-CD45RB (HB220) and 250 ug of antiCD40L (MR1) was administered on days $0,1,3,5$, and 7 posttransplant; both antibodies were from BioXCell (Lebanon, $\mathrm{NH}$ ). Anti-interferon- $Y$ (XMG1.2, BioXCell) was administered on days $0,1,3,5$, and 7 post-transplant either at 200 ug or 600 ug per dose. Euthanasia was by cervical dislocation under Avertin anesthesia (125-250 mg/kg IP).
For pain management, animals designated for transplant were administered pre-emptive analgesia for post-operative pain control. The first dose of analgesic was given 30 minutes prior to the initiation of the surgical procedure. Buprenex 0.05 to $0.1 \mathrm{mg} / \mathrm{kg} \mathrm{sc} \mathrm{q} \mathrm{8-12} \mathrm{hrs} \mathrm{was} \mathrm{administered} \mathrm{for} \mathrm{the} \mathrm{first} 3$ days post-procedure. In addition, the animals were kept warm and monitored for one hour post-transplant, then at least daily for the first week to assess the general health status of the mouse as well as look for signs of distress. After the first week, the animals were examined 2-3 times per week until graft rejection.

A skin graft is not a life-threatening procedure, and transplant recipients recover quickly and generally do not die. Any animal in the study that exhibited lethargy, weight loss, ruffled fur, an abnormal appearance, or any other serious health condition was euthanized humanely.

\section{Cell preparation and flow cytometry}

Single cell suspensions were generated from spleens and peripheral lymph nodes by passage through a $70 \mu \mathrm{M}$ nylon cell strainer followed by RBC lysis buffer (Sigma-Aldrich). Cells were stimulated in Complete Medium (RPMI 1640 containing $10 \%$ fetal bovine serum (HyClone FetalClone III, Thermo Scientific), $50 \mu \mathrm{M}$ 2-mercaptoethanol (ACROS Organics), 1 $\mathrm{mM}$ sodium pyruvate, NEAA, $2 \mathrm{mM}$ L-glutamine, $100 \mathrm{IU} \mathrm{mL} \mathrm{m}^{-1}$ Penicillin, and $100 \mu \mathrm{g} \mathrm{mL}$ Streptomycin, all from MP Biomedicals) with PMA (50 $\mathrm{ng} \mathrm{mL}^{-1}$, Sigma), ionomycin $(1 \mu \mathrm{g}$ $\mathrm{mL}^{-1}$, Sigma), monensin (GolgiStop; $4 \mu \mathrm{g} \mathrm{mL}^{-1}, \mathrm{BD}$ ), and either with or without LPS $\left(10 \mu \mathrm{g} \mathrm{mL}^{-1}\right.$ Escherichia coli serotype 0111 : B4, Sigma) in 6 well tissue culture treated plates for 5 hours in a $37^{\circ} \mathrm{C} / 5 \% \mathrm{CO}_{2}$ incubator.

Cells were surface stained at $4^{\circ} \mathrm{C}$ in FACS buffer (PBS containing $2 \% \mathrm{FBS}$ and $0.1 \%$ sodium azide) in 96 well plates, with $2 \times 10^{6}$ cells per well. Fc receptors were blocked with purified anti-Mouse CD16/CD32 (2.4G2, BD Pharmingen) prior to cell surface staining. Fluorescently labeled mAbs were used for the following markers: CD4 (GK1.5, Biolegend), B220 (RA3-6B2, Biolegend), CD8 (53-6.7, eBioscience), CD62L (MEL-14, eBioscience), and CD44 (IM7, BD).

Intracellular staining was performed using the Intracellular Staining Buffer Set (eBioscience) according to the manufacturer's instructions. Cells were stained with fluorescently labeled $m A b s$ or non-specific isotypes for the following markers: IFN-Y (XMG1.2), IL-10 (JES5-16E3), all from eBioscience. Samples were run on a LSRII flow cytometer (BD Biosciences) and analyzed using FlowJo software (Tree Star, Inc.).

\section{Statistical analysis}

Data were analyzed using GraphPad Prism (version 5, GraphPad Software). Graft survival between experimental groups was compared using Kaplan-Meier survival curves and Wilcoxon statistics. Other differences between experimental groups were analyzed using the Student's $t$ test. $P$ values less than 0.05 were considered statistically significant. 


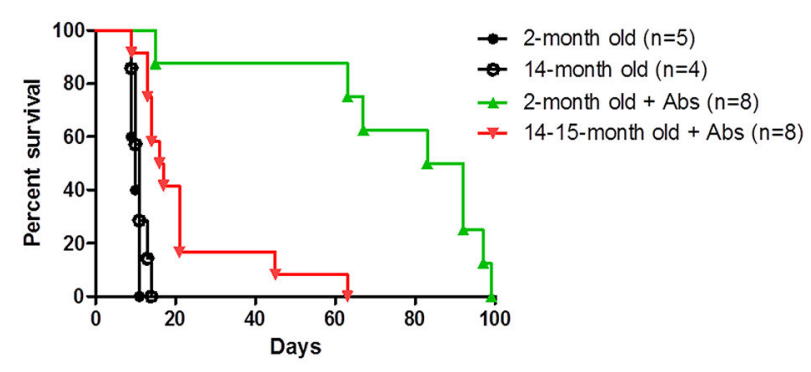

Figure 1. In contrast to young recipients, aged recipients are resistant to transplant tolerance induction. Young C57BL/6 recipients (less than 3-months of age) and aged C57BL/6 recipients (over 12-months of age) reject $\mathrm{C} 3 \mathrm{H} / \mathrm{HeJ}$ skin graft at same tempo. When treated with anti-CD45RB and anti-CD154 antibodies, $50 \%$ of skin grafts survive over 80 days. In contrast, antibodytreated aged recipients reject quickly (aged MST $=16.5$ days versus young MST $=87.5$ days, $p>0.001^{* *}$ ).

doi: 10.1371/journal.pone.0082856.g001

\section{Results}

\section{Ageing impairs tolerance induction to skin grafts}

As previously reported, aged recipients are resistant to antiCD45RB antibody-mediated transplant tolerance to heart allografts. In young anti-CD45RB-treated C57BL/6 recipients, roughly $60 \%$ of $\mathrm{C} 3 \mathrm{H} / \mathrm{H} 3 \mathrm{~J}$ heart grafts survive long-term $(>100$ days), while $\mathrm{C} 3 \mathrm{H} / \mathrm{HeJ}$ heart grafts are rapidly rejected in aged recipients (greater than one year-old [29]) receiving the same antibody treatment. Using the same strain combination, we examined whether age-dependent tolerance resistance could also be extended to skin grafts. Both untreated young and old C57BL/6 skin graft recipients reject $\mathrm{C} 3 \mathrm{H} / \mathrm{HeJ}$ skin grafts at the same tempo (Figure 1). $\mathrm{C} 3 \mathrm{H} / \mathrm{HeJ}$ donors are less than three months old. When treated with anti-CD45RB plus anti-CD40L, $50 \%$ of young $\mathrm{C} 57 \mathrm{BL} / 6$ recipients grafted with $\mathrm{C} 3 \mathrm{H} / \mathrm{HeJ}$ skin survive greater than 80 days, however, median survival time for antibody-treated aged recipients is 16.5 days (Figure 1). Neither antibody extends graft survival in young recipients (data not shown). Thus, as with heart grafts, aged recipients are also resistant to prolongation of skin graft survival.

\section{Elevated production of IFN-y in aged animals}

To understand the basis for this resistance to tolerance induction in old mice, we examined whether their $\mathrm{T}$ cell cytokine profile differed from that of $T$ cells from young mice. We compared interferon- $\gamma$ production by CD4+ and CD8+ T cells in spleen and lymph node (LNC) of young versus old mice. IFN- $\gamma$ production by memory $T$ cells has correlated with acute renal rejection $[18,19]$, and we hypothesized that IFN- $\gamma$ production in aged animals would be higher than in young. Overall, the percentages of lymphocytes comprising the spleen were not significantly altered, but we did observe a decrease in the percentage of CD4+ $\mathrm{T}$ cells in aged naive male mice (Figure S1). In naive male animals, a significantly higher percentage of $\mathrm{CD} 4+$ and $\mathrm{CD} 8+\mathrm{T}$ cells from aged mice produced IFN-y than from young mice (Figure 2) suggesting a possible mechanism of tolerance resistance in aged recipients.

\section{Memory T cell expansion results in elevated IFN-Y production by aged animals}

We next examined which subset of T cells - Tnaive or Tmem - produced the elevated levels of IFN-y. Tmem have a decreased threshold of activation and are resistant to costimulatory blockade [17], thus, an increased percentage of Tmem would play a significant contribution to transplant tolerance resistance. Spleens from naive aged mice, despite being housed in germ-free conditions, exhibited a significant increase in the percentage of both CD4+ and CD8+ memory $T$ cells (Figure $\mathbf{3 A}$ ) compared to naive young mice. Lymph nodes were not examined.

We next examined whether the frequency of IFN- $\mathrm{y}$-producing Tmem or Tnaive was higher in aged animals versus naive animals. By gating on naive CD4+ and CD8+ $\mathrm{T}$ cells in unchallenged young and old animals we found a higher percentage of naive $\mathrm{T}$ cells produce IFN- $\mathrm{Y}$ in aged animals compared to young animals, yet overall fewer than $2 \%$ of the naive $\mathrm{T}$ cell populations produced IFN-Y (Figure 3B). When we examined IFN-y production by memory $\mathrm{T}$ cells, we observed a significantly higher percentage of IFN- $\gamma^{+}$memory CD4+ and CD8+ $T$ cells in aged mice compared to those in young mice. These data suggest that IFN- $\gamma$ production by Tmem may be involved in age-dependent transplant tolerance resistance.

Next we examined the impact of transplantation on the percentage of Tmem. We hypothesized that memory $T$ cells in transplanted aged recipients would exhibit more robust expansion than memory $\mathrm{T}$ cells in young recipients. Male mice received a skin graft, and spleens were analyzed at two weeks post-transplantation. In young recipients, there is an increase in both CD4+ and CD8+ Tmem after skin graft transplantation which was not statistically significant. In contrast, in aged recipients, there is a statistically significant increase in both CD4+ and CD8+ Tmem after transplantation (Figure 3A). Most importantly, IFN-y production by CD4+ T cells of transplanted aged recipients rises with antibody treatment, while young recipients' CD4+IFN- $\gamma$ production decreases back to baseline levels (Figure 2). These data suggest that the increase in tolerance resistance in aged mice may be related to the failure of antibody treatment to control IFN-y production by Tmem. 

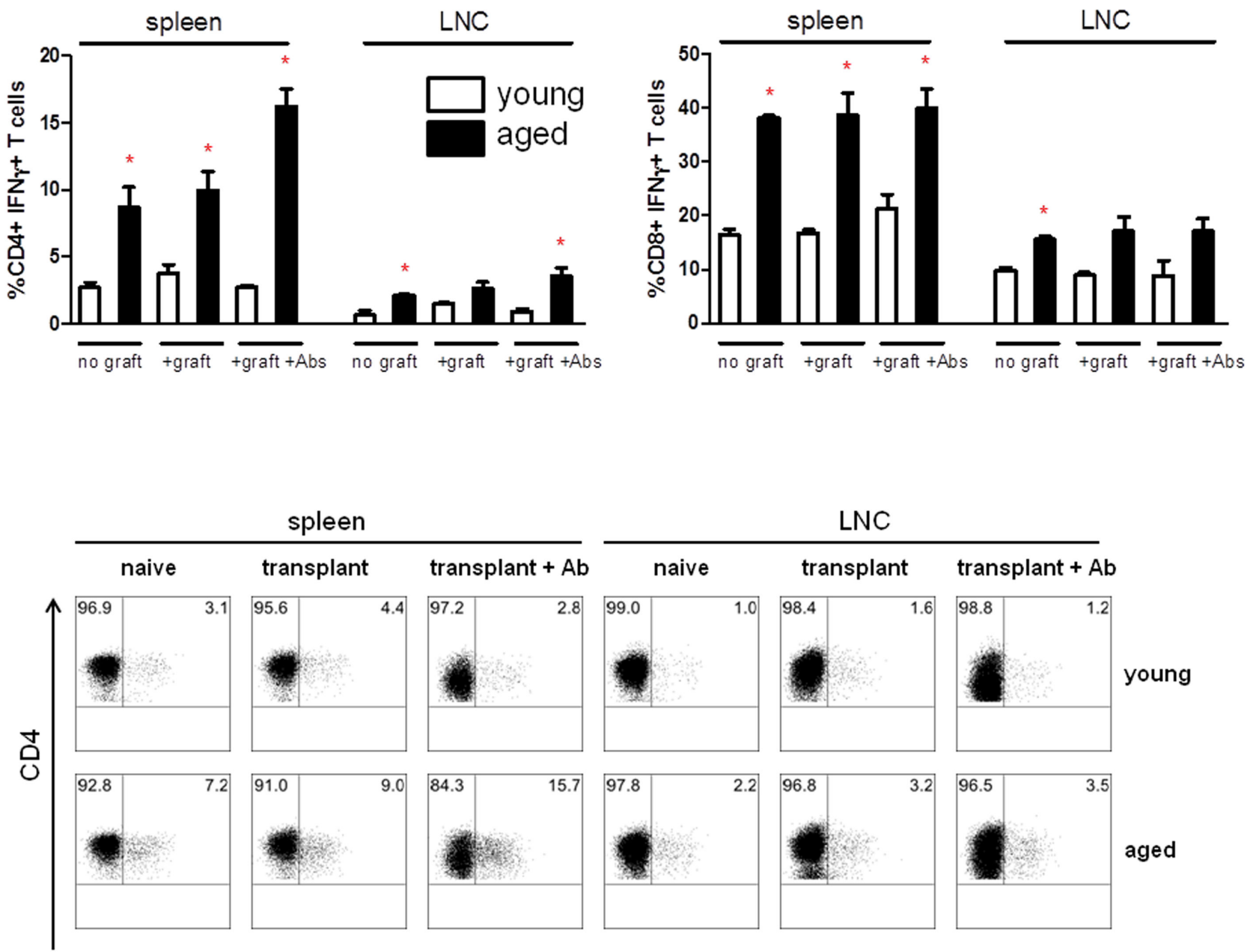

spleen

LNC

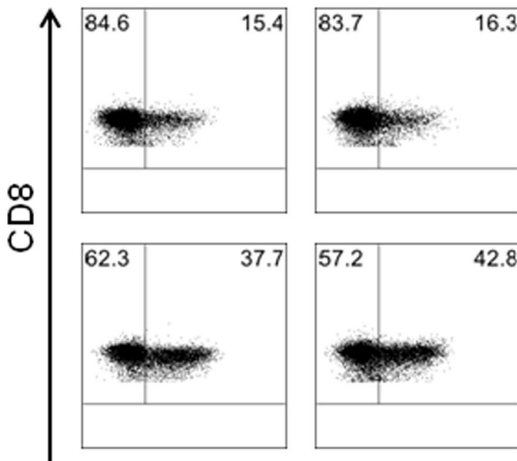

transplant $+\mathrm{Ab}$

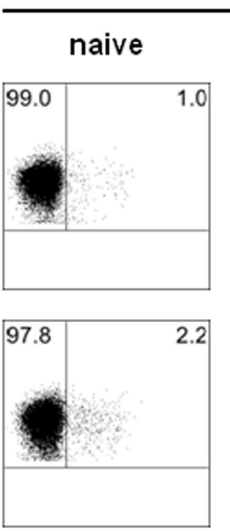

\section{transplant}

transplant $+\mathrm{Ab}$
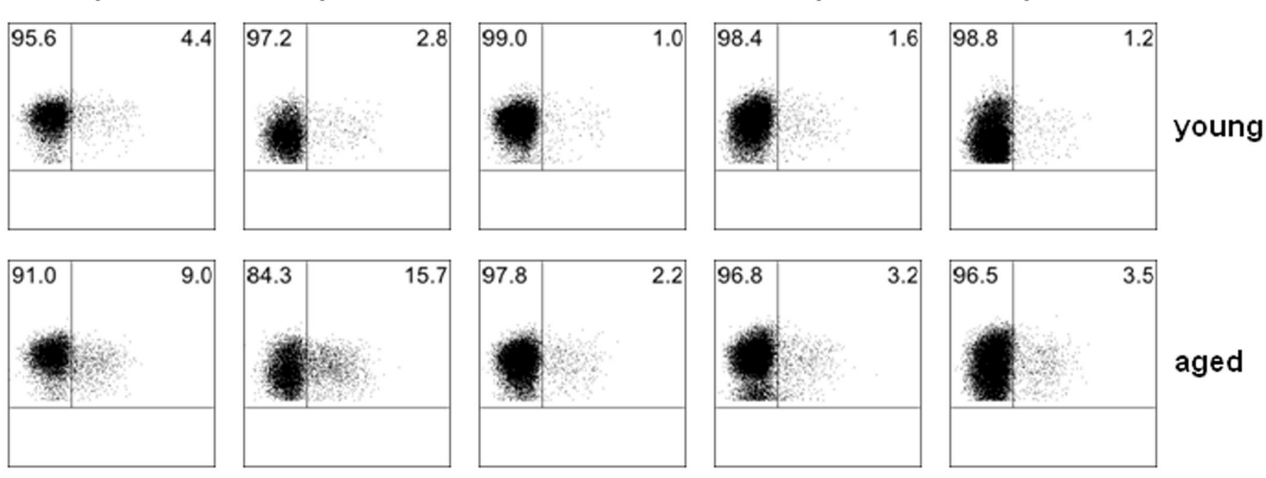

aged
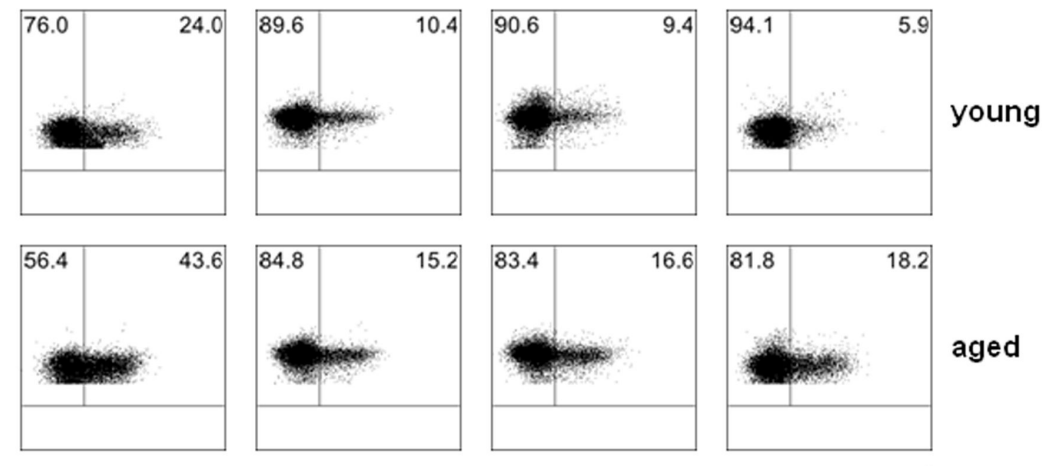

IFN- $\gamma$

Figure 2. A higher percentage of both CD4 and CD8 T cells from aged animals produce IFN-y relative to those from young animals. Spleen and lymph node (LNC) from naive animals, grafted animals, and grafted, anti-CD45RB / anti-CD154-treated animals were examined 14 days after transplant, $p<0.05^{*}$. Representative FACS plots are shown, bottom. 2 to 3 animals were examined independently in each group.

doi: 10.1371/journal.pone.0082856.g002

We next examined whether IL-10 levels were altered in young male mice versus aged male mice. IL-10 is also a critical cytokine in Th1/Th2 development, and elevated levels of IL-10 and Th2 cytokines correlates with prolonged graft survival [32-34]. We hypothesized that IL-10 production would be significantly lower in aged mice as a result of elevated IFN-Y 
A
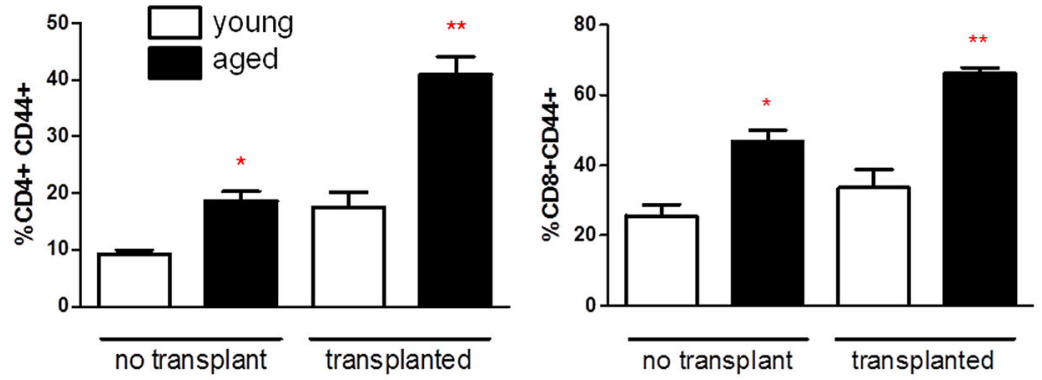

B
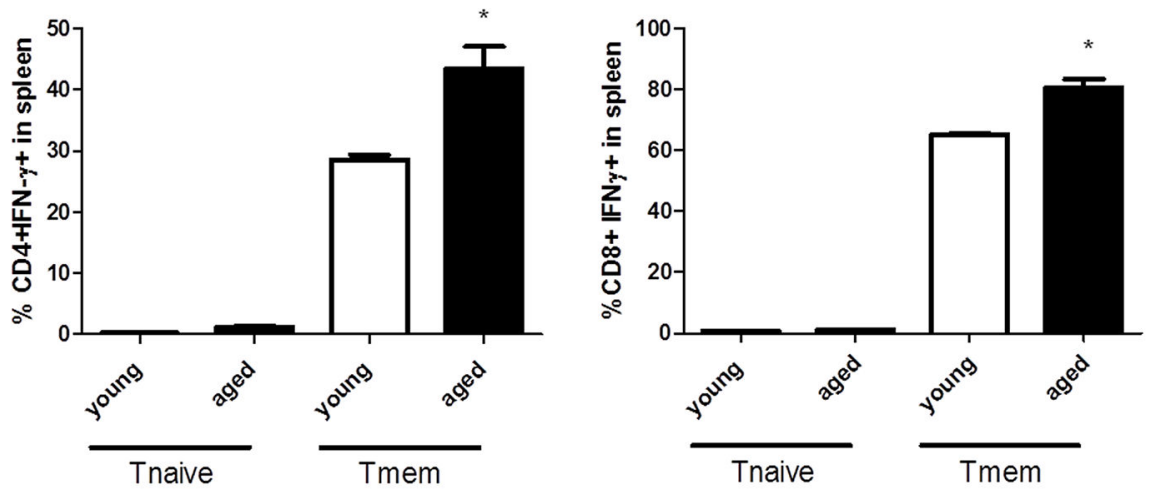

Figure 3. Memory $\mathrm{T}$, not naive $\mathrm{T}$, exhibit elevated production of IFN-y, in young and old animals. (A) CD4 and CD8 memory $\mathrm{T}$ cells expand in aged animals. Young and aged animals, with and without skin graft, were examined for memory $\mathrm{T}$ cells 14 days post-transplant. At least two to three animals were examined independently per group. (B) Splenocytes were examined for CD4, CD8, CD44, and IFN-y expression. Tnaive cells were gated as CD4+ CD44low or CD8+ CD44low, while Tmem were gated as CD44hi. The percentage of IFN- $y+$ cells is plotted on the $y$-axis. At least two to three animals were examined independently per group.

doi: $10.1371 /$ journal.pone.0082856.g003

production. IL-10 levels by B cells and CD4+ and CD8+ T cells were unchanged in young male versus aged male mice (Figure 4).

\section{Castration does not significantly modulate percentage of IFN- $\mathrm{Y}$-producing $\mathrm{T}$ cells}

We have previously demonstrated that castration restores tolerance to aged, tolerance-resistant recipients [29]. We examined whether modulation of IFN- $\gamma$ production correlated with the restoration of tolerance. Grafted and non-grafted aged animals were castrated, and spleen and draining lymph node were examined two weeks post-transplant. Castration was performed 30 days prior to transplant. Grafted C57BL/6 mice were transplanted with $\mathrm{C} 3 \mathrm{H}$ skin grafts and treated with antiCD40L / anti-CD45RB antibodies for one week. In the absence of a skin graft, castration did reduce the percentage of IFN- $\gamma^{+} \mathrm{T}$ cells in the draining lymph node, however, overall, and especially in the transplant setting, there was no significant difference in castrated versus non-castrated groups (Figure 5).
When we specifically examining activated CD4+ CD44+ T cells, still we did not observe any significant difference between castrated and non-castrated groups (data not shown). Thus, these data suggest the elevated levels of IFN- $\gamma$-producing $T$ cells may not be the cause of tolerance resistance in aged transplant recipients.

\section{Neutralization of IFN-Y does not restore antibody- mediated tolerance induction}

To further define the role of increased IFN-y secretion, we neutralized this cytokine in the aged animals by anti-interferon$\mathrm{Y}$ neutralizing antibody. We used two different doses of antiIFN-Y antibody (clone XMG1.2) to see if we could prolong graft survival as well as to see if there was a dosage effect. We utilized a previously reported regimen [35], and the high dose of anti-IFN-Y antibody was sufficient to accelerate graft rejection in a young recipient (Figure S2). C57BL/6 mice were transplanted with $\mathrm{C} 3 \mathrm{H}$ skin grafts and treated with anti-CD40L / anti-CD45RB antibodies with or without co-injection of anti- 


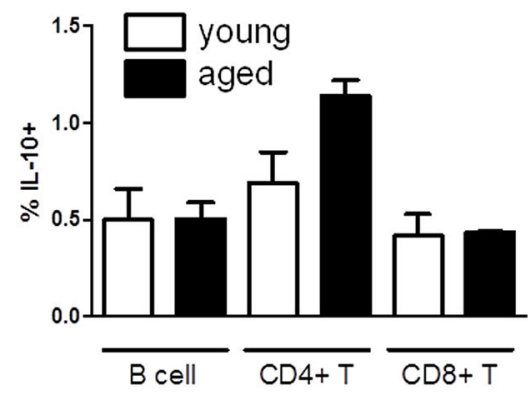

Figure 4. Young and aged animals exhibit similar levels of IL-10 production. Spleen was examined for B220, CD4, CD8, and $\mathrm{IL}-10$. Y-axis indicates percentage of $\mathrm{B} 220+, \mathrm{CD} 4+$, or CD8+ cells that were IL-10+. At least two to three animals were examined independently per group.

doi: 10.1371/journal.pone.0082856.g004
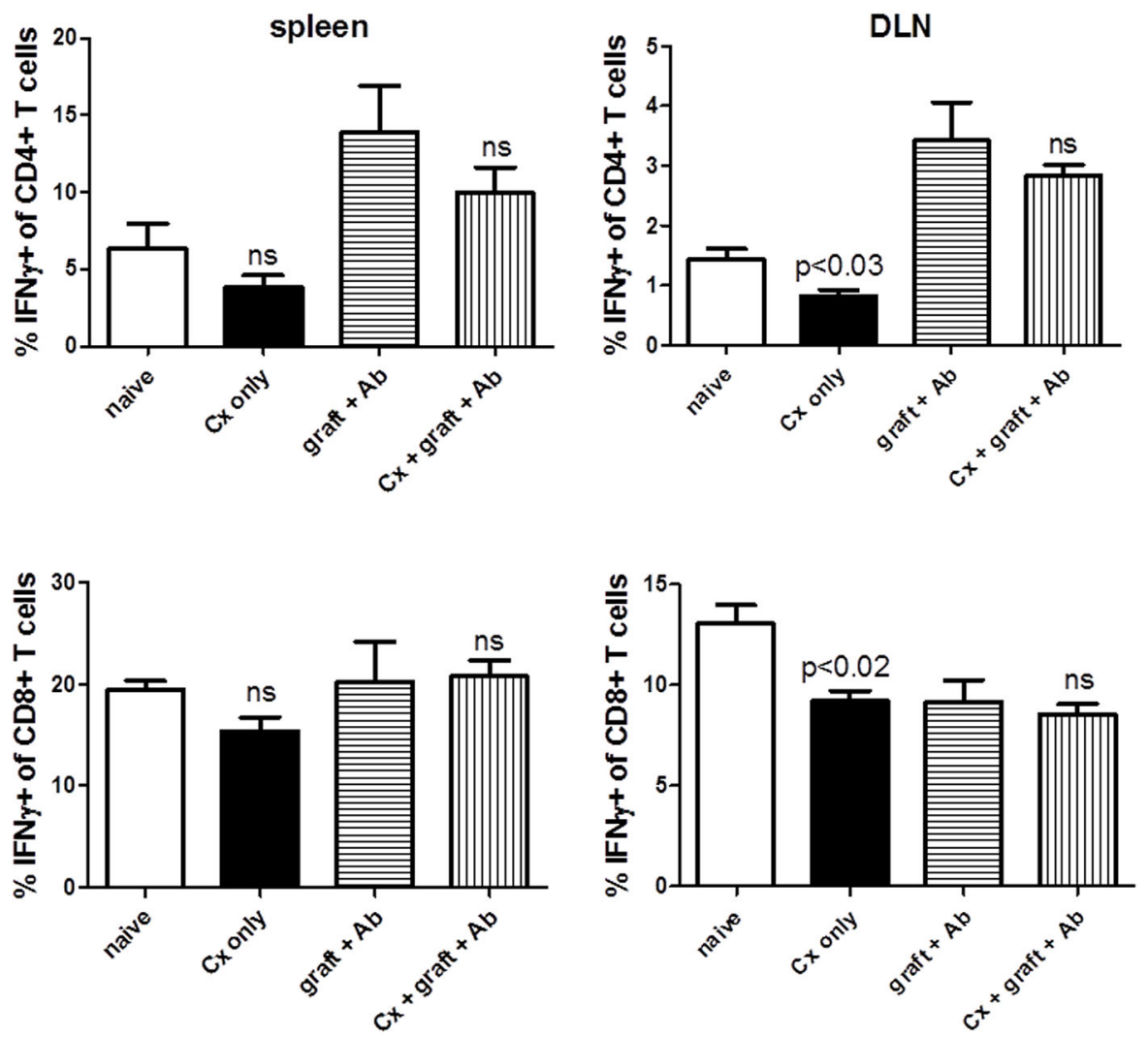

Figure 5. Castration does not significantly modulate levels of CD4+ IFN- $\mathbf{y}+$ and CD8+ IFN- $\mathbf{\gamma}+\mathrm{T}$ cells. The effect of castration was examined on CD4+ and CD8+ T cells from spleen and lymph node of ungrafted and grafted, antibody-treated animals. Intracellular IFN- $y$ was examined two weeks after skin graft. Castration was performed 30 days before skin graft. In the absence of a skin graft, castration reduced the $\%$ of IFN $-\gamma+\mathrm{T}$ cells in the lymph node, however, overall, castration did not significantly affect the percentages of IFN-Y production.

doi: 10.1371/journal.pone.0082856.g005

interferon- $y$ neutralizing antibody (Figure 6). While we observed a modest prolongation in median survival time, neither dose of anti-interferon-y resulted in a statistically significant prolongation of skin graft survival.

\section{Discussion}

Our work and the work of others suggest that anti-CD45RB treatment promotes the differentiation of Th2 cells and that this 


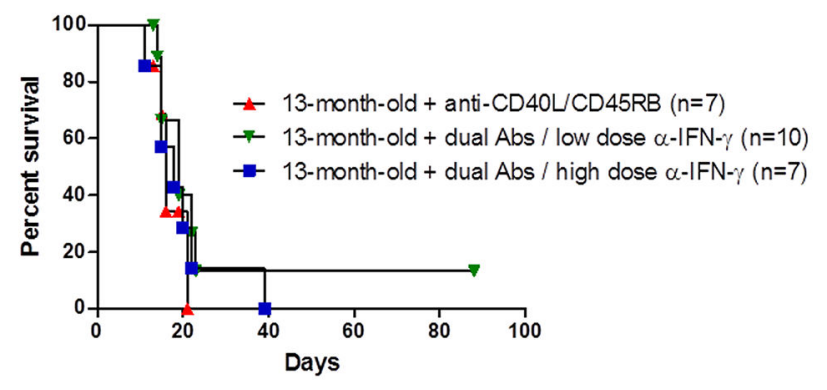

Figure 6. Neutralizing anti-interferon-y antibody does not prolong graft survival in aged recipients. C57BL/6 mice received $\mathrm{C} 3 \mathrm{H}$ skin grafts and were treated with anti-CD40L/anti-CD45RB antibodies with or without anti-interferon-y antibodies (low dose at $200 \mathrm{ug}$ or high dose at $600 \mathrm{ug}$ ). All antibodies were injected every other day for one week starting on the day of transplant.

doi: 10.1371/journal.pone.0082856.g006

Th1/Th2 shift is critical to the tolerogenic effect of anti-CD45RB $\mathrm{Ab}$ [36]. Both in human and in mouse, ageing has been demonstrated to be associated with a Th1-Th2 imbalance or a diminished Th1-Th2 response [37], but the data are conflicting. Aged humans have been reported to have increased Th1 [37,38], decreased Th1 [39], increased Th2 [37,38], and decreased Th2 [39]. Similar conflicting reports exist for mice, but such tendencies also result from mouse strain and experimental model differences [40-44]. The effects of ageing on Th1/Th2 in an allograft response remain unclear. Our data suggest that anti-CD45RB antibody maintains low levels of CD4 IFN-y, a hallmark Th1 cytokine, in grafted young recipients (Figure 2). However, upon antibody treatment, aged, grafted animals produce significantly elevated levels of IFN-y relative to young, grafted, antibody treated animals $\left({ }^{* *} p<0.01\right)$ $[19,30]$. The molecular mechanism underlying this elevated IFN-y expression remains unknown.

Interferon- $\gamma$ is a potent inducer of cellular immunity. IFN-Y may act directly to promote CD8 T cell responses, and it may act indirectly by skewing CD4 Th cells towards Th1 [45]. In young recipients treated with anti-IFN- $y$ neutralizing antibody or in IFN-y-deficient recipients, $T$ cell costimulatory blockade resulted in decreased survival of allografts relative to wild-type or untreated recipients. It was hypothesized that the absence of interferon- $\gamma$ resulted in uncontrolled proliferation of activated $T$ cells and subsequent accelerated rejection [46-48]. InterferonY may also act on the graft to promote its survival [49]. Consistent with this, we found that treatment of young C57BL/6 recipients with high dose anti-interferon- $\gamma$ resulted in more rapid rejection.

Memory CD8 T cells have been demonstrated to secrete high levels of IL-2 and IFN- $y$ in both mouse and in human $[8,50,51]$. Our in vitro data demonstrate that CD4 and CD8 Tmem, particularly Tmem of aged animals, are skewed towards the production of IFN-y. While both Tmem and Tnaive may differentiate into IFN- $\gamma$-producing cells in vivo, because Tmem respond more quickly, they are likely to skew the overall response. However, this high proportion of IFN-y-producing $\mathrm{T}$ cells may be due to the genetic propensity of B6 to skew towards Th1. In humans, the frequency of pre-transplant
Tmem, as measure by in vitro IFN- $\mathrm{y}$ production, correlated with risk of acute renal allograft rejection $[18,19]$.

Despite housing in a germ-free facility, Tmem in aged animals are likely to arise either through heterologous activation to an infectious agent or by bystander proliferation [52-55]. Yet since these Tmem were not generated by sensitization to a previous transplant, it is surprising that these cells would still pose such a formidable barrier to transplant tolerance [56]. The barrier is unlikely due simply to precursor frequency of alloreactive cells. By ELISpot, Du et al. demonstrated that the frequency of alloreactive cells in aged mice pre-transplant was no greater than that in young animals. Consistent with survival data, only after transplant and $A b$ treatment was there a significant difference in the frequency of alloreactive cells between young and aged animals.

We hypothesized that the increased IFN-Y production that we observed in aged mice was responsible for tolerance resistance, and that the IFN- $\gamma$ production might in turn be controlled by hormones. However, neither dose of anti-IFN-Y prolonged survival in aged recipients (Figure 6). Most skin grafts survived beyond 15 days, and potentially a dosing regimen in which anti-IFN- $\gamma$ antibody was administered beyond just the first week might have significantly prolonged graft survival. Castration also had no effect on IFN-Y production in aged mice, further suggesting IFN- $\gamma$ alone does not mediate tolerance resistance in aged mice, since castrated, aged mice are no longer resistant to tolerance induction.

Based on our data and the work of others in the effects of ageing on allograft transplantation outcome, we hypothesized that elevated $\mathrm{T}$ cell interferon- $\mathrm{\gamma}$ production interfered with tolerance induction. However, our data suggest that this elevated IFN- $\mathrm{\gamma}$ production may not contribute to the tolerance resistance observed with age, and perhaps interferon- $\gamma$ is but a marker of memory $\mathrm{T}$ cells which accumulate with age. Indeed, IFN-Y neutralization did prolong graft survival in aged mice. More potent therapies involving $\mathrm{T}$ cell depletion and costimulatory blockade of ICOS and CD28/B7 have demonstrated significant graft survival prolongation in young recipients and should be examined in old recipients $[57,58]$.

At the time of puberty and linked with an increase in sex steroid levels, the thymus atrophies $[59,60]$. This dramatic age- 
related change results in a significant reduction in thymic size, overall thymocyte cell number, and the absolute number of single-positive CD4+ and CD8+ T cells that leave the thymus $[61,62]$. Castration has been demonstrated to restore thymic architecture, improve adaptive immunity in both sexes, alter lymphocyte cytokine profile, and in some cases, reverse the Th1/Th2 differences $[49,60,63-66]$. We previously reported that castration did restore thymic architecture. Our current finding that neutralization of IFN- $\mathrm{Y}$ does not affect tolerance resistance and that castration does not change IFN-y levels would tend to favor the importance of thymic rejuvenation and output in the immunological alterations seen in aged mice.

\section{Supporting Information}

Figure S1. The percentages of lymphocytes in the spleen of an old mouse are not significantly different from that of a young mouse. Antibodies to CD4, CD8, and B220 were used to stain splenocytes of young and old mice, and cells were analyzed by flow cytometry. Percentage of CD4+ cells

\section{References}

1. Crespo-Leiro MG, Paniagua MJ, Rodriguez JA, Hermida LF, Fojón S et al. (1999) Morbidity and mortality among heart transplant patients older and younger than 65 years. Transplant Proc 31: 2537-2538. doi: 10.1016/S0041-1345(99)00453-4. PubMed: 10500706.

2. Martins PN (2009) Impact of donor and recipient age on allograft tolerance. Exp. Clin Transplant 7: 67-77.

3. Miller RA (1996) The aging immune system: primer and prospectus. Science 273: 70-74. doi:10.1126/science.273.5271.70. PubMed: 8658199.

4. Rosenberg AS, Sechler JM, Horvath JA, Maniero TG, Bloom ET (1994) Assessment of alloreactive $T$ cell subpopulations of aged mice in vivo. CD4+ but not CD8+ $T$ cell-mediated rejection response declines with advanced age. Eur J Immunol 24: 1312-1316. doi:10.1002/eji. 1830240611. PubMed: 7911422

5. United Nations PD (2002) Magnitude and speed of population ageing. World Population Ageing: 1950-2050.

6. Maffi P, Bertuzzi F, De Taddeo F, Magistretti P, Nano R et al. (2007) Kidney function after islet transplant alone in type 1 diabetes: impact of immunosuppressive therapy on progression of diabetic nephropathy. Diabetes Care 30: 1150-1155. doi:10.2337/dc06-1794. PubMed: 17259471.

7. Paroni R, Fermo I, Fiorina P, Cighetti G (2005) Determination of asymmetric and symmetric dimethylarginines in plasma of hyperhomocysteinemic subjects. Amino Acids 28: 389-394. doi: 10.1007/s00726-005-0191-z. PubMed: 15827687.

8. Alberti S, Cevenini E, Ostan R, Capri M, Salvioli S et al. (2006) Agedependent modifications of Type 1 and Type 2 cytokines within virgin and memory CD4+ T cells in humans. Mech Ageing Dev 127: 560-566. doi:10.1016/j.mad.2006.01.014. PubMed: 16516272.

9. De Greef GE, Van Tol MJ, Kallenberg CG, Van Staalduinen GJ, Remarque EJ et al. (1992) Influence of ageing on antibody formation in vivo after immunisation with the primary T-cell dependent antigen Helix pomatia haemocyanin. Mech Ageing Dev 66: 15-28. doi: 10.1016/0047-6374(92)90070-T. PubMed: 1340513.

10. Deans GD, Stiver HG, McElhaney JE (2010) Influenza vaccines provide diminished protection but are cost-saving in older adults. J Intern Med 267: 220-227. doi:10.1111/j.1365-2796.2009.02201.x. PubMed: 20175868.

11. Hobbs MV, Ernst DN, Torbett BE, Glasebrook AL, Rehse MA et al. (1991) Cell proliferation and cytokine production by CD4+ cells from old mice. J Cell Biochem 46: 312-320. doi:10.1002/jcb.240460406. PubMed: 1684583.

12. Makinodan T, Hahn TJ, McDougall S, Yamaguchi DT, Fang M et al. (1991) Cellular immunosenescence: an overview. Exp Gerontol 26: 281-288. doi:10.1016/0531-5565(91)90021-D. PubMed: 1915697.

13. Grubeck-Loebenstein B, Della Bella S, Iorio AM, Michel JP, Pawelec G et al. (2009) Immunosenescence and vaccine failure in the elderly. decreased with age $(20.7 \%+/-1.1$ versus $14.5 \%+/-0.9, \mathrm{p}<0.01)$. Data represent two independent experiments and 5 mice. Young mice were 2 months of age, and old mice were over 12 months of age.

(TIF)

Figure S2. High dose anti-IFN-gamma accelerates graft rejection. Young C57BL/6 mice were grafted with $\mathrm{C} 3 \mathrm{H} / \mathrm{HeJ}$ skin and treated with anti-CD40L plus anti-CD45RB antibodies with or without anti-IFN-gamma antibody. Recipients receiving additional IFN-gamma antibody exhibited accelerated graft rejection.

(TIF)

\section{Author Contributions}

Conceived and designed the experiments: JIK RTS JS HY SD JFM. Performed the experiments: JIK RTS JS KL GZ. Analyzed the data: JIK RTS JS HY SD JFM. Wrote the manuscript: JIK HY JFM.
Aging Clin Exp Res 21: 201-209. doi:10.1007/BF03324904. PubMed: 19571643.

14. McElhaney JE, Effros RB (2009) Immunosenescence: what does it mean to health outcomes in older adults? Curr Opin Immunol 21: 418-424. doi:10.1016/j.coi.2009.05.023. PubMed: 19570667.

15. McEniery CM, Yasmin, McDonnell B, Munnery M, Wallace SM et al. (2008) Central pressure: variability and impact of cardiovascular risk factors: the Anglo-Cardiff Collaborative Trial II. Hypertension 51: 1476-1482. doi:10.1161/HYPERTENSIONAHA.107.105445. PubMed: 18426997.

16. Gruver AL, Hudson LL, Sempowski GD (2007) Immunosenescence of ageing. J Pathol 211: 144-156. doi:10.1002/path.2104. PubMed: 17200946.

17. Adams AB, Pearson TC, Larsen CP (2003) Heterologous immunity: an overlooked barrier to tolerance. Immunol Rev 196: 147-160. doi: 10.1046/j.1600-065X.2003.00082.x. PubMed: 14617203.

18. Augustine JJ, Siu DS, Clemente MJ, Schulak JA, Heeger PS et al. (2005) Pre-transplant IFN-gamma ELISPOTs are associated with posttransplant renal function in African American renal transplant recipients. Am J Transplant 5: 1971-1975. doi:10.1111/j.1600-6143.2005.00958.x. PubMed: 15996247.

19. Heeger PS, Greenspan NS, Kuhlenschmidt S, Dejelo C, Hricik DE et al. (1999) Pretransplant frequency of donor-specific, IFN-gammaproducing lymphocytes is a manifestation of immunologic memory and correlates with the risk of posttransplant rejection episodes. J Immunol 163: 2267-2275. PubMed: 10438971.

20. Kostakis ID, Moris DN, Barlas A, Bokos I, Darema M et al. (2013) Impact of donor and recipient age difference on long-term allograft survival after living donor renal transplantation: analysis of 478 cases. Clin Transplant: ([MedlinePgn:]) PubMed: 23991890.

21. Sesso R, Josephson MA, Anção MS, Draibe SA, Sigulem D (1998) A retrospective study of kidney transplant recipients from living unrelated donors. J Am Soc Nephrol 9: 684-691. PubMed: 9580370.

22. Molnar MZ, Streja E, Kovesdy CP, Shah A, Huang E et al. (2012) Age and the associations of living donor and expanded criteria donor kidneys with kidney transplant outcomes. Am J Kidney Dis 59: 841-848. doi:10.1053/j.ajkd.2011.12.014. PubMed: 22305759.

23. Lee YJ, Chang JH, Choi HN, Jung JY, Kim YS et al. (2012) Donorrecipient age difference and graft survival in living donor kidney transplantation. Transplant Proc 44: 270-272. doi:10.1016/ j.transproceed.2011.12.013. PubMed: 22310630.

24. Meier-Kriesche HU, Ojo AO, Cibrik DM, Hanson JA, Leichtman AB et al. (2000) Relationship of recipient age and development of chronic allograft failure. Transplantation 70: 306-310. doi: 10.1097/00007890-200007270-00012. PubMed: 10933154.

25. Meier-Kriesche $\mathrm{H}$, Ojo AO, Arndorfer JA, Port FK, Magee JC et al. (2001) Recipient age as an independent risk factor for chronic renal 
allograft failure. Transplant Proc 33: 1113-1114. doi:10.1016/ S0041-1345(00)02452-0. PubMed: 11267215.

26. Bradley BA (2002) Rejection and recipient age. Transpl Immunol 10: 125-132. doi:10.1016/S0966-3274(02)00058-8. PubMed: 12216942.

27. Deng S, Moore DJ, Huang X, Mohiuddin M, Lee MK et al. (2006) Antibody-induced transplantation tolerance that is dependent on thymus-derived regulatory $T$ cells. J Immunol 176: 2799-2807. PubMed: 16493036.

28. Lazarovits AI, Poppema S, Zhang Z, Khandaker M, Le Feuvre CE et al. (1996) Prevention and reversal of renal allograft rejection by antibody against CD45RB. Nature 380: 717-720. doi:10.1038/380717a0. PubMed: 8614467.

29. Zhao G, Moore DJ, Kim JI, Lee KM, O'Connor MR et al. (2011) Inhibition of transplantation tolerance by immune senescence is reversed by endocrine modulation. Sci Transl Med 3: 87ra52. PubMed: 21677198.

30. Du W, Shen H, Galan A, Goldstein DR (2011) An age-specific CD8+ T cell pathway that impairs the effectiveness of strategies to prolong allograft survival. J Immunol 187: 3631-3640. doi:10.4049/jimmunol. 1100441. PubMed: 21873523.

31. Billingham RE, Medawar PB (1951) The technique of free skin grafting in mammals. J Exp Biol 28: 385

32. Takeuchi T, Lowry RP, Konieczny B (1992) Heart allografts in murine systems. The differential activation of Th2-like effector cells in peripheral tolerance. Transplantation 53: 1281-1294. doi: 10.1097/00007890-199206000-00023. PubMed: 1351322.

33. Dallman MJ, Wood KJ, Hamano K, Bushell AR, Morris PJ et al. (1993) Cytokines and peripheral tolerance to alloantigen. Immunol Rev 133: 5-18. doi:10.1111/j.1600-065X.1993.tb01507.x. PubMed: 8225371.

34. Sayegh MH, Akalin E, Hancock WW, Russell ME, Carpenter CB et al. (1995) CD28-B7 blockade after alloantigenic challenge in vivo inhibits Th1 cytokines but spares Th2. J Exp Med 181: 1869-1874. doi: 10.1084/jem.181.5.1869. PubMed: 7536798.

35. Markees TG, Phillips NE, Gordon EJ, Noelle RJ, Shultz LD et al. (1998) Long-term survival of skin allografts induced by donor splenocytes and anti-CD154 antibody in thymectomized mice requires CD4(+) T cells, interferon-gamma, and CTLA4. J Clin Invest 101: 2446-2455. doi: 10.1172/JCl2703. PubMed: 9616216.

36. Rothstein DM, Livak MF, Kishimoto K, Ariyan C, Qian HY et al. (2001) Targeting signal 1 through CD45RB synergizes with CD40 ligand blockade and promotes long term engraftment and tolerance in stringent transplant models. J Immunol 166: 322-329. PubMed: 11123308.

37. Rink L, Cakman I, Kirchner H (1998) Altered cytokine production in the elderly. Mech Ageing Dev 102: 199-209. doi:10.1016/ S0047-6374(97)00153-X. PubMed: 9720652.

38. Sandmand $M$, Bruunsgaard $H$, Kemp $K$, Andersen-Ranberg $K$, Pedersen AN et al. (2002) Is ageing associated with a shift in the balance between Type 1 and Type 2 cytokines in humans? Clin Exp Immunol 127: 107-114. doi:10.1046/j.1365-2249.2002.01736.x. PubMed: 11882040.

39. Karanfilov Cl, Liu B, Fox CC, Lakshmanan RR, Whisler RL (1999) Agerelated defects in Th1 and Th2 cytokine production by human T cells can be dissociated from altered frequencies of CD45RA+ and CD45RO $+T$ cell subsets. Mech Ageing Dev 109: 97-112. doi:10.1016/ S0047-6374(99)00030-5. PubMed: 10515660.

40. Ide K, Hayakawa H, Yagi T, Sato A, Koide Y et al. (1999) Decreased expression of Th2 type cytokine mRNA contributes to the lack of allergic bronchial inflammation in aged rats. J Immunol 163: 396-402. PubMed: 10384141.

41. Kovacs EJ, Duffner LA, Plackett TP (2004) Immunosuppression after injury in aged mice is associated with a TH1-TH2 shift, which can be restored by estrogen treatment. Mech Ageing Dev 125: 121-123. doi: 10.1016/j.mad.2003.11.007. PubMed: 15037015.

42. Segal R, Dayan M, Globerson A, Habut B, Shearer GM et al. (1997) Effect of aging on cytokine production in normal and experimental systemic lupus erythematosus afflicted mice. Mech Ageing Dev 96: 47-58. doi:10.1016/S0047-6374(97)01891-5. PubMed: 9223110.

43. Smith P, Dunne DW, Fallon PG (2001) Defective in vivo induction of functional type 2 cytokine responses in aged mice. Eur J Immunol 31: 1495-1502. doi:10.1002/1521-4141(200105)31:5. PubMed: 11465106.

44. Tesar BM, Du W, Shirali AC, Walker WE, Shen H et al. (2009) Aging augments IL-17 T-cell alloimmune responses. Am J Transplant 9: 54-63. PubMed: 18976294.

45. Glimcher LH (2001) Lineage commitment in lymphocytes: controlling the immune response. J Clin Invest 108: s25-s30. doi:10.1172/ JCl200113455. PubMed: 11669073

46. Bishop DK, Chan Wood S, Eichwald EJ, Orosz CG (2001) Immunobiology of allograft rejection in the absence of IFN-gamma:
CD8+ effector cells develop independently of CD4+ cells and CD40CD40 ligand interactions. J Immunol 166: 3248-3255. PubMed: 11207279

47. Kishimoto K, Sandner S, Imitola J, Sho M, Li Y et al. (2002) Th1 cytokines, programmed cell death, and alloreactive $\mathrm{T}$ cell clone size in transplant tolerance. J Clin Invest 109: 1471-1479. doi:10.1172/ JCI0214947. PubMed: 12045261

48. Konieczny BT, Dai Z, Elwood ET, Saleem S, Linsley PS et al. (1998) IFN-gamma is critical for long-term allograft survival induced by blocking the CD28 and CD40 ligand T cell costimulation pathways. J Immunol 160: 2059-2064. PubMed: 9498741.

49. Coley SM, Ford ML, Hanna SC, Wagener ME, Kirk AD et al. (2009) IFN-gamma dictates allograft fate via opposing effects on the graft and on recipient CD8 T cell responses. J Immunol 182: 225-233. PubMed: 19109153.

50. Zimmermann C, Prévost-Blondel A, Blaser C, Pircher H (1999) Kinetics of the response of naive and memory CD8 T cells to antigen: similarities and differences. Eur J Immunol 29: 284-290. doi:10.1002/ (SICl)1521-4141(199901)29:01. PubMed: 9933110.

51. Ortiz-Suárez A, Miller RA (2002) A subset of CD8 memory T cells from old mice have high levels of CD28 and produce IFN-gamma. Clin Immunol 104: 282-292. doi:10.1006/clim.2002.5221. PubMed: 12217339.

52. Adams AB, Williams MA, Jones TR, Shirasugi N, Durham MM et al. (2003) Heterologous immunity provides a potent barrier to transplantation tolerance. J Clin Invest 111: 1887-1895. doi:10.1172/ $\mathrm{JCl} 200317477$. PubMed: 12813024

53. Brook MO, Wood KJ, Jones ND (2006) The impact of memory T cells on rejection and the induction of tolerance. Transplantation 82: 1-9. doi: 10.1097/01.tp.0000245501.53813.49. PubMed: 16861933.

54. Oldstone MB (1987) Molecular mimicry and autoimmune disease. Cell 50: 819-820. doi:10.1016/0092-8674(87)90507-1. PubMed: 3621346.

55. Tough DF, Borrow P, Sprent J (1996) Induction of bystander T cell proliferation by viruses and type I interferon in vivo. Science 272: 1947-1950. doi:10.1126/science.272.5270.1947. PubMed: 8658169.

56. Trambley J, Bingaman AW, Lin A, Elwood ET, Waitze SY et al. (1999) Asialo GM1(+) CD8(+) T cells play a critical role in costimulation blockade-resistant allograft rejection. J Clin Invest 104: 1715-1722. doi: 10.1172/JCl8082. PubMed: 10606625.

57. Ansari MJ, Fiorina P, Dada S, Guleria I, Ueno T et al. (2008) Role of ICOS pathway in autoimmune and alloimmune responses in NOD mice. Clin Immunol 126: 140-147. doi:10.1016/j.clim.2007.07.019. PubMed: 17889619.

58. Vergani A, D'Addio F, Jurewicz M, Petrelli A, Watanabe T et al. (2010) A novel clinically relevant strategy to abrogate autoimmunity and regulate alloimmunity in NOD mice. Diabetes 59: 2253-2264. doi: 10.2337/db09-1264. PubMed: 20805386.

59. Gray DH, Seach N, Ueno T, Milton MK, Liston A et al. (2006) Developmental kinetics, turnover, and stimulatory capacity of thymic epithelial cells. Blood 108: 3777-3785. doi:10.1182/ blood-2006-02-004531. PubMed: 16896157

60. Hince M, Sakkal S, Vlahos K, Dudakov J, Boyd R et al. (2008) The role of sex steroids and gonadectomy in the control of thymic involution. Cell Immunol 252: 122-138. doi:10.1016/j.cellimm.2007.10.007. PubMed: 18294626

61. Luettig B, Sponholz A, Heerwagen C, Bode U, Westermann J (2001) Recent thymic emigrants $(\mathrm{CD} 4+)$ continuously migrate through lymphoid organs: within the tissue they alter surface molecule expression. Scand J Immunol 53: 563-571. doi:10.1046/j. 1365-3083.2001.00897.x. PubMed: 11422904

62. Sempowski GD, Gooding ME, Liao HX, Le PT, Haynes BF (2002) T cell receptor excision circle assessment of thymopoiesis in aging mice. Mol Immunol 38: 841-848. doi:10.1016/S0161-5890(01)00122-5. PubMed: 11922942.

63. Gourdy P, Araujo LM, Zhu R, Garmy-Susini B, Diem S et al. (2005) Relevance of sexual dimorphism to regulatory $T$ cells: estradiol promotes IFN-gamma production by invariant natural killer $\mathrm{T}$ cells. Blood 105: 2415-2420. doi:10.1182/blood-2004-07-2819. PubMed: 15383462

64. Heng TS, Goldberg GL, Gray DH, Sutherland JS, Chidgey AP et al. (2005) Effects of castration on thymocyte development in two different models of thymic involution. J Immunol 175: 2982-2993. PubMed: 16116185

65. Hirakata A, Okumi M, Griesemer AD, Shimizu A, Nobori S et al. (2010) Reversal of age-related thymic involution by an LHRH agonist in miniature swine. Transpl Immunol 24: 76-81. doi:10.1016/j.trim. 2010.08.001. PubMed: 20692342

66. Perisic M, Arsenovic-Ranin N, Pilipovic I, Kosec D, Pesic V et al. (2010) Role of ovarian hormones in age-associated thymic involution revisited. 
Immunobiology 215: 275-293. doi:10.1016/j.imbio.2009.06.012.

PubMed: 19577818. 